\title{
Kaoping Shelf: morphology and tectonic significance
}

\author{
Ho-Shing $\mathrm{Yu}$ and Cheng-Shing Chiang \\ Division of Marine Geology and Geophysics. Institute of Oceanography. National Taiwan \\ llniversity. Taipei, Taiwan. ROC
}

(Received 20 April 1996: aceepted for puhlication 28 September 1990)

\begin{abstract}
Thirty bathymetric profiles across the southwestern Taiwan margin reveal two distinct physiographic features: a shelf and a slope separated at Fangliao. The Kaoping Shelf northwest of Fangliao is the offshore extension of the Pingtung Valley. and the unnamed slope west of the Hengchun Peninsula is a part of the submerged southern Central Range. The Kaoping Shelf is a short, narrow and shallow shelf $(100 \mathrm{~km}$ long, $20 \mathrm{~km}$ wide and $80 \mathrm{~m}$ deep). This shelf can be divided into two subshelves. The one to the north is terraced with an average width of $28 \mathrm{~km}$ and the other to the south is a very narrow $(9 \mathrm{~km})$ and shallow $(40 \mathrm{~m})$ platform. The average gradient $(5 \mathrm{~m} / \mathrm{km})$ of the shelf is greater than that $(2.5 \mathrm{~m} \mathrm{~km})$ of the average shelf worldwide. The width of the shelf. ranging from 7 to $40 \mathrm{~km}$, increases progressively from southeast to northwest and is a factor of 24 narrower thin that of others in the world. The gradient and width reflect the youthful stage of development of the Kaoping Shelf. The seaward progradation of the sediments from the coastal plain of the Pingtung Valley resulted in the prograding Kaoping Shelf, as suggested by cored sediment samples and seismic profiles. The morphology of the Kaoping Shell depends manly on the tectonic setting of the uplifted Taiwaln orogen and the aceompanying foreland-basin sedimentation. This young (less than 400,000 yearsi shelf is still growing and prograding southward in at parallel direction with the southward propagating arc continent collision in the Taiwan region. + 1997 Elsevier Science Ltd
\end{abstract}

\section{Introduction}

\section{Geological setting}

The island of Taiwan is located at the junction between the Ryukyu Arc and the Luzon Arc along the rim of the Western Pacific (Fig. 1). The oblique collision between the Luzon Arc and the Chinese continental margin during the period from the Late Miocene to the present has resulted in the formation of Taiwan Island (Suppe. 1981; Ho, 1986; Teng, 1990). The collision is still actively propagating to the south (Suppe. 1987). Moreover, the arc-continent collision in the Taiwan orogen resulted in a foreland basin and a mountain belt in the west and east, respectively (Covey, 1984) (Fig. 1).

The western Taiwan foreland basin covers the hilly Western Foothill, the Coastal Plain and its offshore areas. This basin is mainly filled with Pliocene Pleistocene sediments up to more than $5 \mathrm{~km}$ thick (Covey. 1984). The geological framework of the study area in southwestern Taiwan, including the Pingtung Valley, was established during Late Pliocene and Pleistocene. The Pingtung Valley lies between the Central Range to the east and a low hilly upland to the west. The $\mathrm{N}-\mathrm{S}$ trending Chaochou Fault separates the Pingtung Valley from the Central Range. Tectonically. the Pingtung Valley is considered to be a foredeep related to the Manila Trench subduction zone (Biq, 1977). This valley is actively subsiding today (Ho, 1982). Regionally. the southwestern Taiwan margin is a growing foreland basin receiving sediments from the Taiwan orogen (Yu, 1993). The mountain ranges of Taiwan. including the prominent Central Range, are fold-thrust belts of Tertiary strati. They extend from north to south throughout the island. The Central Range south of Fangliao is called Hengchun Peninsula (Fig. 1)

\section{Prerious studies}

In their pioneering investigations of sediment properties of the shelf and slope around Taiwan Island, Boggs of al. (1979) pointed out that the shelf edge around the island can be placed at the $200 \mathrm{~m}$ isobath, which reveals a distinct asymmetry of the sea-floor topography around Taiwan (Fig. 2). It should be noted that the istand of Taiwan is bordered by the shallow Taiwan Strait Shelf 10 the west and a deep-water $(3-5 \mathrm{~km})$ region of the Philippine Sea to the east. The width of Taiwan Strait Shelf ranges from 140 to $200 \mathrm{~km}$ and at major portion of the shelf is covered by water shallower than $60 \mathrm{~m}$. Off the castern coast. the shelf is very narrow and the sea floor descends to the $3000 \mathrm{~m}$ isobath no more than $1 \mathrm{~km}$ beyond the coastline.

Across the southwestern Taiwan margin, the sea floor passes a narrow shelf and descends to a depth of about $.000 \mathrm{~m}$ at the northern end of the abyssal plain of the South China Sea. Morphologically, the southwestern Taiwan margin is characterized by a very narrow shelf and a broad southwest-facing slope. $Y u$ and Wen (1992) named the shelf along the southwestern Taiwan margin the Kaoping Shelf, characterized by narrow width and shallow depth. The Kaoping Shelf extends for about $150 \mathrm{~km}$ from the southern tip of the island of Taiwan to the Tsengwen Hsi River mouth. where it merges gradually into the broad Taiwan Strait Shelf (Fig. 2). This shelf was considered to be the natural prolongation of the Coastal Plain and the southern Central Range of Taiwan. Furthermore. Yu and Wen (1992) noted that a distinct character of this shelf is the marked change in 
its structural trend. The shelf extends from the southern tip of the island northward parallel to the mountainous coast, and then it turns sharply at Fangliao and the nearby Chaochou Fault northwestward running along the shoreline of the Coastal Plain. The structural trend of the shelf changes from a $\mathrm{N}-\mathrm{S}$ direction in the south to a NW $-\mathrm{SE}$ trend to the northwest at the Chaochou Fault (Fig. 2).

The shelfbreak, a distinct physiographic feature between the shelf and slope, along the southwestern Taiwan margin has received little attention. Lp to 1995. only a single paper of $\mathrm{Yu}$ and Wen (1992) pointed out the significance of the shelfbreak along the southwestern Taiwan margin. They realized that the shelf edge off southwestern Taiwan is much shallower than the presumed $200 \mathrm{~m}$ isobath (Boggs et al., 1979). The true depth of the Kaoping Shell edge was $n 01$ completely mapped because of inadequate bathymerric data. Emphasizing the tectonic style of the southwestern Taiwan margin, $Y u$ (1993) suggested that this margin belongs to the destructional stage (convergent type $F$ in terms of the Emery (1980) classification).

\section{Objectives}

The objectives of this paper are (1) to describe the overall morphology of the Kaoping Shelf: (2) to define the areal extent of this shelf: (3) io determine the true depth of the shelf edge; and (4) to examine the primary factors controlling the development of this shelf:

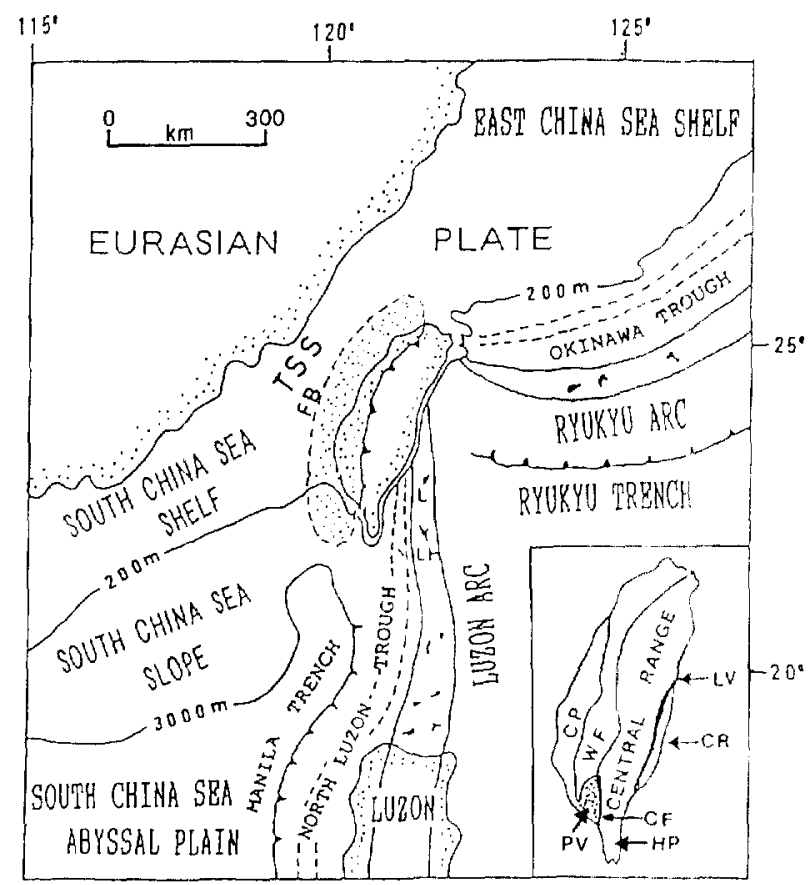

Fig. 1. Geological setting of Taiwan, which is localed at the junction of the Ryukyu Are and the Luzon Are along the western rim of the Pacific. Note that the forcland hasin to the west and the mountain range to the east occupy Taiwan Island modified from Covey (1984) and $Y u$ and Chilo (1994). TSS, Taiwan Strait Shelf; FB, Foreland Basin; CP. Coattal Plain; WF. Western Foothill; LV. Longitudinal Valley: CR. Coutstal Range: PV. Pingtung Valley: CF, Chaochou lault: HP. Hengchun Peninsula.

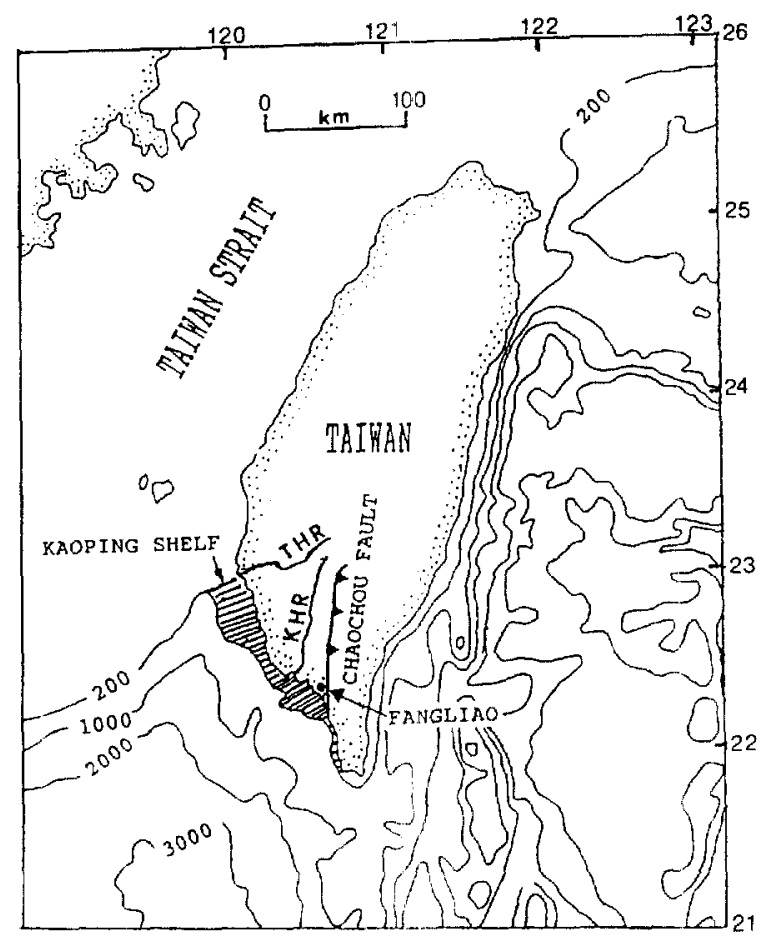

Fig. 2. Location and areal extent of the Kaoping Shelf tafter Yu and Wen, 1992). This shelf extends from the southern tip of the island northward parallel to the mountainous coast. and it then turns at Fanglialo and the nearby Chatochou Fault northwestward running along the shoreline of the Coastal Plain and ends at the mouth of the Thengwen Hsi River. Water depth in meters. THR. Tsengwen Hsi River; KHR. Kaoping Hoi Rive

\section{Data and method}

Bathymetric transects and four-channel seismic reflection profiles were acquired on board $\mathrm{R} V \mathrm{O}$ Ocean Rexarcher I from 1993 to 1995 . In addition. three box cores on the shelf were also collected to determine the sediment type using a standard sieving technique. The ocations of bathymetric protiles and cored samples are shown in Fig. 3.

Thirty bathymetric transects with an average spacing of about $5 \mathrm{~km}$ along the roughly $150-\mathrm{km}$ southwestern Taiwan margin were examined to determine the outline and dimensions of the shelf. The ship tracklines were aligned as closely as possible perpendicularly to the isobaths in order to reveal the maximum slope angle of the shelf:

The position and depth of the shelfbreak of the Kaoping Shelf were determined mechanically following the guidelines of Vanney and Sianley (198.3) as shown in lig. 4. These authors realize that the echo-sounding and $3.5-\mathrm{kHz}$ sub-bottom profiling surveys generally generate an artificial sea-floor shape resulting from high vertical exaggeration ranging from $\times 10$ to $\times 40$. Bathymetric profiles of this study were displayed with $\times 10$ vertical exaggeration for mechanical identification of the major break of the gradient along the bathymetric profiles.

Thirty bathymetric profiles can be classified into four protile forms. Examples of each type taken from real profiles are shown in Fig. 4. 


\section{Shelf and slope}

Analyses of thirty bathymetric transects across the shallow water areas off southwestern Tawan coast reveal two major types of sea-floor morphology: a shelf and a slope. Northwest of Fangliao and the nearby Chaochou Fault, profiles 1-4 display a terraced shelf (Fig. 5), and profiles 5-13 exhibit a simple shelf (Fig. 6). However, the terraced shelf grades in to the simple shelf without a well-defined zone of contact. The shelf is located west of the coastal plain of the Pingtung Valley. In contrast to this, south of Fangliao, profiles 14.30 exhibit a steep slope (Fig. 7). This slope region is a part of the western-sloping flank of the submerged southerm Central Range.

Based on morphology and structural trend. the shallow water areas of the southwestern Taiwan margin can be represented by two physiographic features: the NW-SE trending shelf off the coast plain of the Pingtung Valley, and the N.S trending slope west of the Hengchun Peninsula (Fig. 8). The boundary separating these two undersea features can be placed at the coatstal town of Fangliao, where the Kaoping Shelf changes its platform morphology to a straight steep slope. The Fangliao Canyon head passes landward across the shelf and comes in at the Chaochou Fault, defining a boundary between the Kaoping Shelf and the adjacent slope. It is noted that the boundary between the shelf and slope does not seem 10 be transitional. The shelf morphology on profile 13 changes into slope morphology on profile 14 and is subtle and gradual. Clearly, the size of the newly defined Kaoping Shelf is much smaller than that of the Katoping Shelf previously defined by $\mathrm{Yu}$ and Wen (1992). The authors maintain the term Kaoping Shelf for this newly defined smaller shelf. whose geologic significance will be discussed later.

\section{Kaoping Island Shelf}

Since the term of continental shelf has been commonly used to describe the shelves around Taiwan Island, the authors choose the term 'iskand shelf' in a restricted sense to emphasize its physiography and tectonic setting. 'Shelf (continental shelf. island shelf, insular shelf) is defined by Bouma (1990, p. 121) as "a zone adjacent to

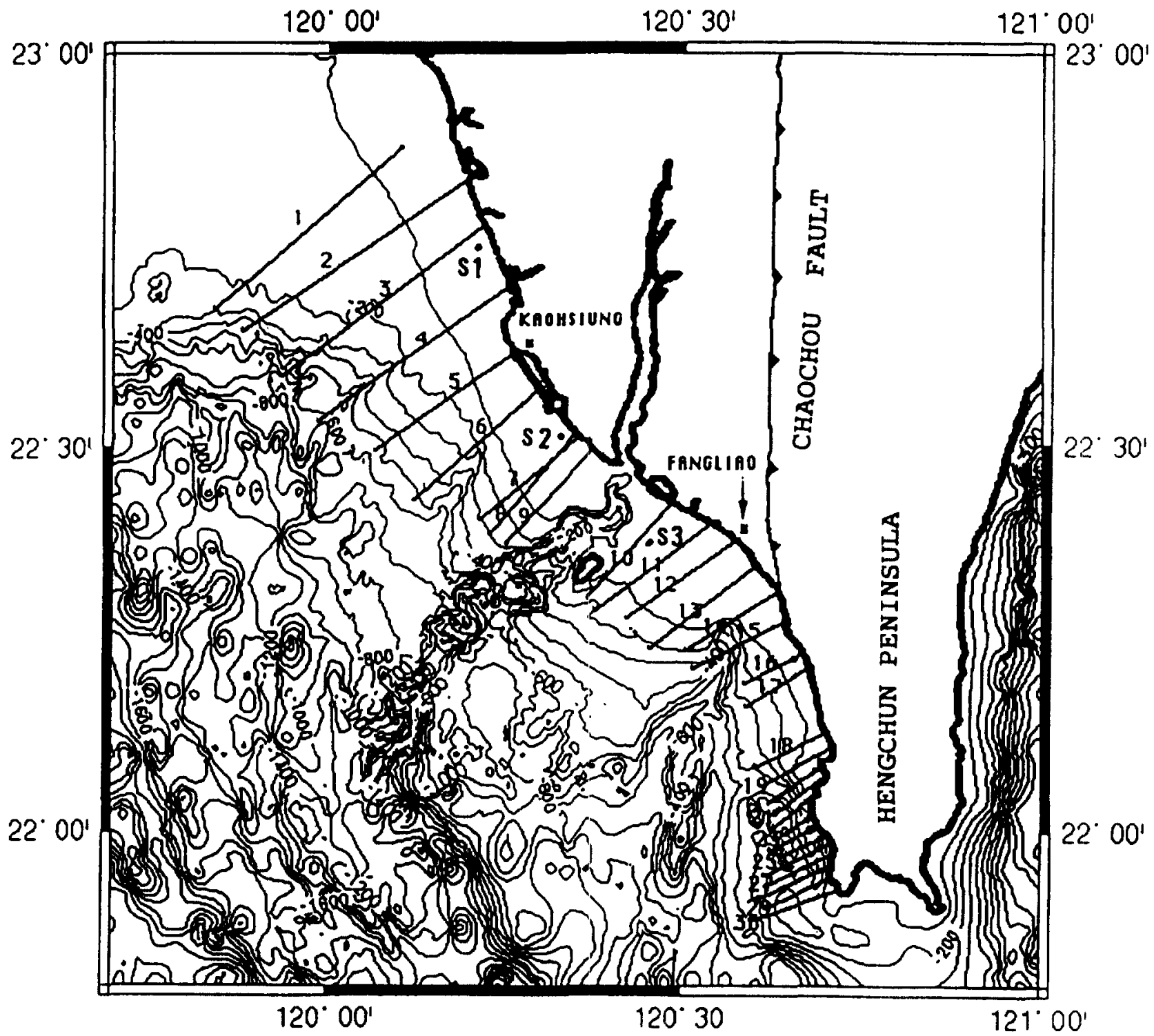

Fig. 3. The locations of bathymetric profites and box-cored sediments (S1. S2 and S31. Watter depth in meters 


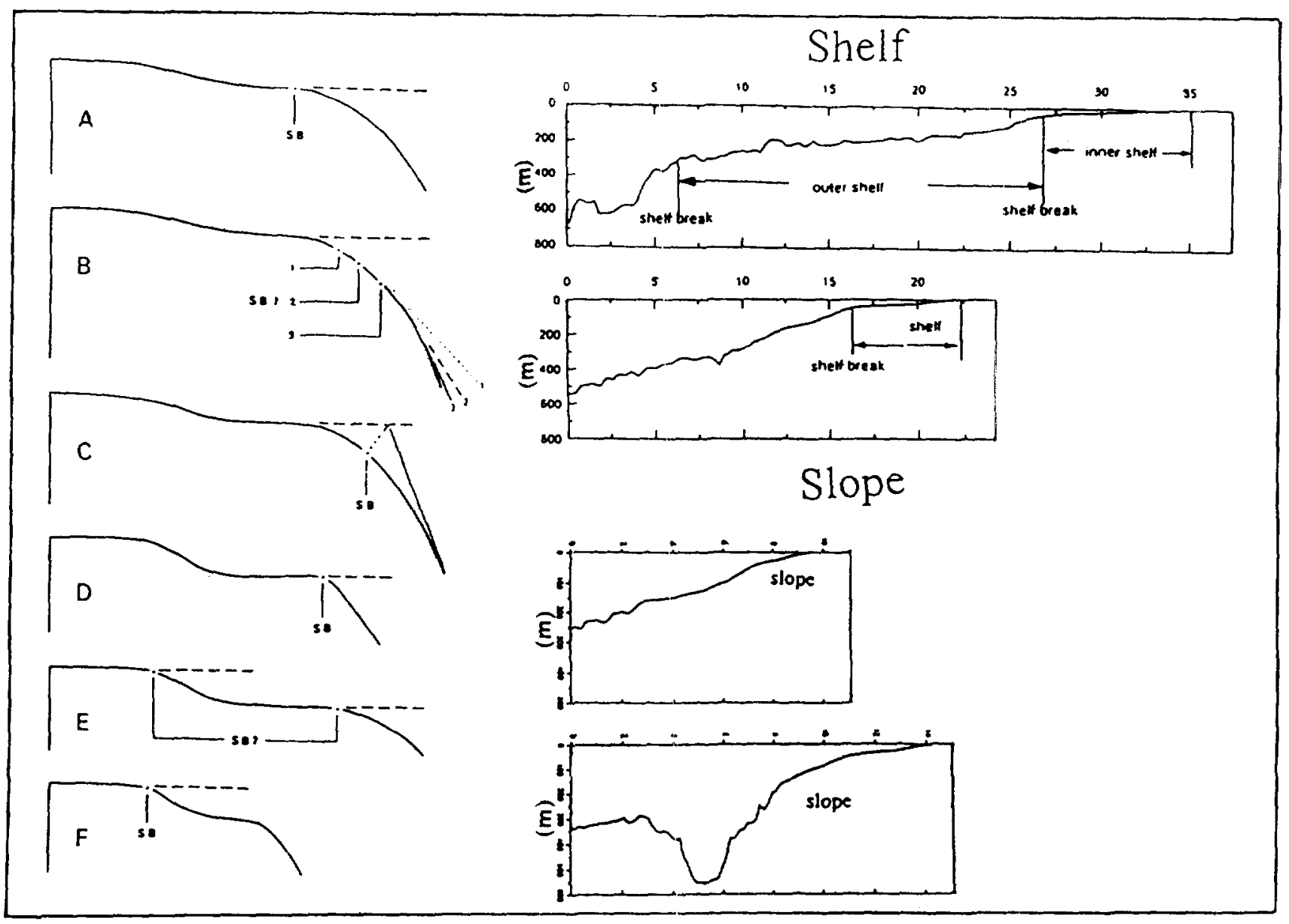

Fig. 4. Method used mechanically to define shelfbreak (SB). Proliles D F show terraced shelves (alter Vanney and Stanley, 1983) as shown in the left column. Thirty protiles across the Kaoping Shelf can be distinguished into four types of profile forms: a terraced shelf a simple shelf. a straight steep slope. and a straight slope cut by a canyon. as shown in a descending order in the right column.
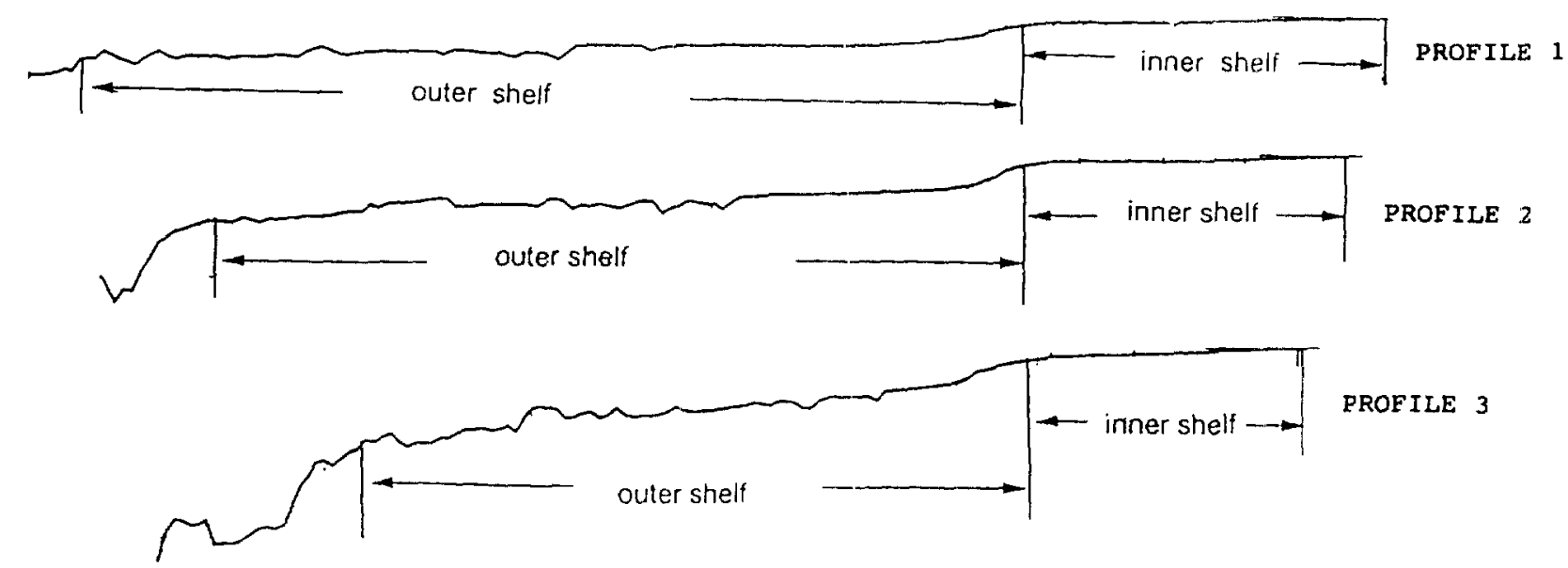

PROFILE 3

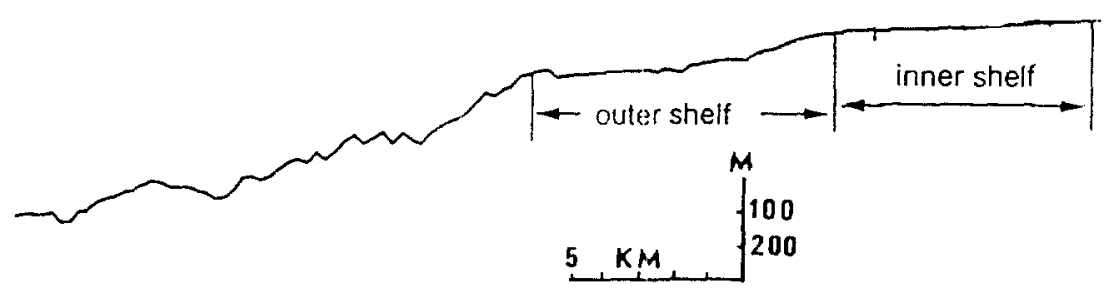

PROFILE 4

Fig. 5. Bathymetric profiles 14 displayed with vertical exaggeratton $\times 10$ show the morphology of terraced shelves. The lecathons of profiles are shown in Fig. 3. 
a continent (or around an island) and extending from the low water line to a depth at which there is usually a marked increase of slope towards oceanic depths". Therefore, the uppermost parts of the sea floor extending seaward from the coastline along the southwestern Taiwan Island to a depth where a marked break of slope occurs is called 'island shelf' here.

Morphologically, the Kaoping Shelf can further be divided into two subshelves at Kaohsiung. North of Kaohsiung, the shelf is terraced (profiles 1-4), whereas the shelf south of Kaohsiung exhibits a relatively smooth platform (profiles 5-13). The terraced shelf (profile 4) grades into the simple shelf (profile 5) with a decrease in shelf width. It appears that the shelf width of $16 \mathrm{~km}$ (profile 4) decreases to a shelf width of $6 \mathrm{~km}$ (profile 5). The terraced shelf consists of an inner shelf $(9 \mathrm{~km}$ wide. $40 \mathrm{~m}$ deep) and an outer shelf ( $20 \mathrm{~km}$ wide, $215 \mathrm{~m}$ deep). It ranges in width from 17 to $40 \mathrm{~km}$, with an average width of $28 \mathrm{~km}$. The average depth of shelfbreak is $215 \mathrm{~m}$ (range $180-250 \mathrm{~m}$ ). In contrast, the relatively smooth shelf south of Kaohsiung is $9 \mathrm{~km}$ wide, ranging from 6.6 to $12 \mathrm{~km}$. The average gradient $(5 \mathrm{~m} / \mathrm{km})$ of the Kaoping Shelf is greater than that $(2.5 \mathrm{~m} / \mathrm{km})$ of the average shelf worldwide (Boillot, 1981; Kennett, 1982). Although locally variable, the width of the shelf increases progressively from southeast to northwest. The width of the Kaoping Shelf is a factor of $2-4$ narrower than that of others in the world. The average width of the shelves of the world is around $80 \mathrm{~km}$ (Boillot. 1981; Kennett, 1982). The East China Sea Shelf north of Taiwan is about $400 \mathrm{~km}$ wide--in other words, one of the widest in the world ( Jin, 1992). Vanney and Stanley (1983) pointed out that the shelfbreak parallels and is usually close to the insular coast in areas of unstable convergent margins, such as some island ares in the tropical Pacific. Therefore, the narrow Kaoping Shelf off the island of Taiwan can be considered a typical island shelf.

The general form of the shelfbreak along the Katoping Shelf is convex-up (Fig. 4). In plan view, the shelf edge does not extend as a straight line (Fig. 8). It should be noted that there is a prominent break in the continuity of the shelf edge where the Kaoping Canyon cuts the shelf deeply and landwards. The shelf edge is gently sinuous.

In summary, the Kaoping Shelf is a very short. narrow and shallow shelf $(100 \mathrm{~km}$ long, $20 \mathrm{~km}$ wide and $80 \mathrm{~m}$ deep). with an average gradient of $5 \mathrm{~m} / \mathrm{km}$. The characteristic morphology of the Kaoping Shelf represents an island shelf situated at an unstable convergent margin.

\section{Modern prograding shelf}

Analyses of three cored sediments reveal that sand is the dominant surface sediment on the shelf north of the Kaoping Canyon, whereas silt is the dominant one south of the canyon. Samples of S1. S2 and S3 contain $77.7 \%$ sand, $19.3 \%$ silt and $3.1 \%$ clay: $60.3 \%$ sand, $37.3 \%$ silt and $2.4 \%$ clay: and $6.8 \%$ sand, $90 \%$ silt and $3.2 \%$ clay. respectively. Boggs et al. (1979) found the presence of a

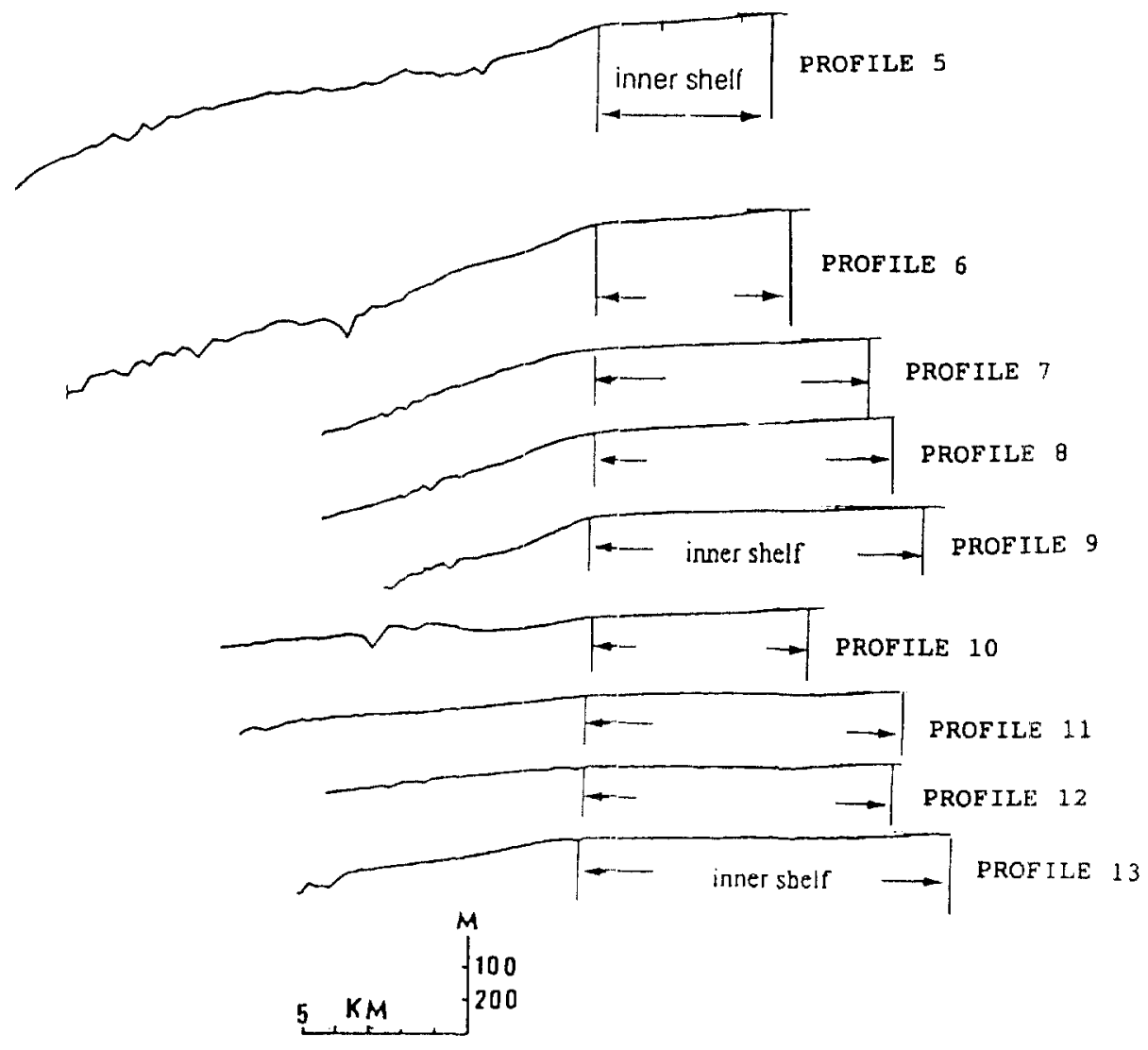

Fig. 6. Bathymetric profiles $5-13$ displayed with vertical exaggeration $\times 10$ exhibit the morphology of a simple shelf characterized by its relatively shallow and narrow form. The location profiles are shown in Fig. 3. 


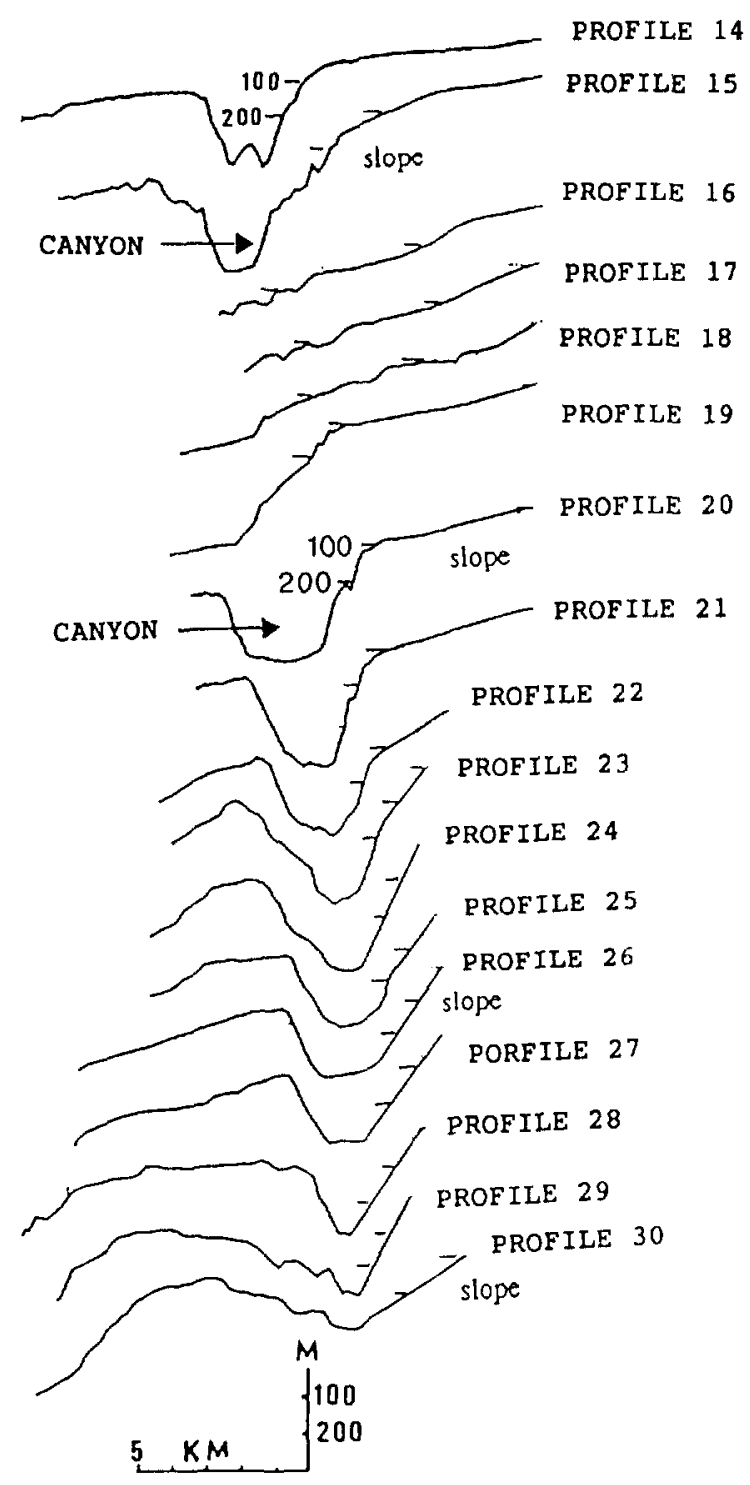

Fig. 7. Bathymetric profiles 14,30 displayed with vertical exaggeration $\times 10$ show the submarine slopes off lae coast of Hengchun Peninsula without the presence of shelf. The locations of profiles atre shown in Fig. 3

continuous nearshore belt of sandy sediments that extends seaward for less than $30 \mathrm{~km}$ along the southwestern Taiwan coast (Fig. 9). It is suggested thal these fine-grained sands on the Kaoping Shellare mainly supplied by the drainage basin of the mator Kaoping Hsi River. Li (1976) estimated that the present-daty average physical denudation rate of the drainage basins of western Taiwan rivers is $1300 \mathrm{mg} \mathrm{cm}$ per war. Which is probably the highest known physical denudation rate in the world. This implies that substantial amount of sediments are available for infilling the cuatsal plain and offshore areas. Comparison of the areal extent of the inner shelf (Fig. s) with the distribution of nearshore sandy sediments (Fig. 9) suggess thall the southwestern coastal plain is prograding satward and sandy sediments atre excaping from Katoping Hi Rivel to the shelf.

Seismic profiles provide some evidence of the processes of progradation and retrogradation associated with the formation of the Katoping Shelf Protile $A$
(Fig. 10), a strike section, is located a short distance from the shoreline. It shows parallel, flat-lying and continuous reflections in the upper part of the section, representing a thin sequence of undeformed sediments deposited in a shallow shelf environment. It is noted that the Kaoping Canyon cuts the shelf. Profile B (Fig. 11) is a downslope section extending from the shelf, crossing the shelfbreak and ending at the upper slope. The northern part of profile $B$ between shot point $X$ and $Y$ shows parallel reflections terminated against the southward dipping sea Hoor, which suggests erosion

The truncation of these reflections could be the result of subaerial erosion during the lowstand of sea level about 15,000 years ago. The sea level during Late Pleistocene is alssumed to have been $140 \mathrm{~m}$ below the present sea level (Boggs (t al., 1979). The Late Pleistocene Kaoping Shelf is considered to be a vetrogradational shelf. On the other hand, the upper section of profile $B$ between shot point $Y$ and $Z$ shows that the sea floor is a strong reflector gently dipping seaward and overlying conformably the underlying subparallel discontinuous reflections. suggesting a prograding shelf during the recent marine transgression. The seismic interpretations integrated into Late Pleistocene sea-level changes suggest that the Kaoping Shelf has undergone cycles of erosion and deposition since Lite Pleistocene.

On the basis of interpretations from the seismic profiles and sediment samples, the authors consider that the Kaoping Shelf is the offshore part of the Pingtung Valley, which is a matture foreland basin receiving a high amount of orogenic sediments. now more than $5 \mathrm{~km}$ lack, from the Central Range. The Coastal Plain in southwestern Taiwan has continuously prograded seaward to build up the shelf and slope. although the process hats been interrupted by sea-level lowering and the shelf was exposed subaerially in Late Pleistocene. As sea level rose in Holocene time, the sediments transported by the major rivers of Kaoping Hsi and Tsengwen Hsi were emptied into the sea and were redistributed on the sea floom, prograding seaward to form the modern Kaoping Shelf

In contrast. the slope region south of Fangliao is in the seting of a prototype foreland basin, receiving litale sediment from the adjacent rising Hengchun Peninsula. where a major river dranage has not developed to supply enough sediment to the sea to build a shelf. It is evident that this slope region does not appeat to be influenced significantly by prostading deposition. which is a common sedimentary process for building a broad shelf. Thus, this slope region is a sediment-slarved area without a plattorm morpholony.

\section{Implications for evolution of shelves in active margins}

Based on 11 surfice section, in the Western Foothills and 17 oil wells drilled in the coastal Platin of western Tainan. Covey (1984) found that the western Taiwan foreland basin lilled with orounce sedments from the westward-migrating Taiman orogen has prograded wothwestward since Late Pliocene. The Pingtung Valley wats mainly filled witl cobble deposits and a belt of Weltac sediments along the cialst about $400,000(1$ years iso (tig. 12(A)). The sedimen: were laid down by the 
ancestral Kaoping Hsi River. Later, orogenic sediments continuously supplied by the Central Range have migrated southwestward and seaward to enlarge the Pingtung Valley to its present position (Fig. 12(B)). The seaward progradation of sediments from the coastal plain of the Pingtung Valley resulted in a prograding shelf, i.e. the present Kaoping Shelf. Assuming the rates of deposition, subsidence and sediment supply being the same as those in the past 400,000 years ago. the authors speculate that in the future, 400,000 years from now, the foreland basin in front of the southern Central Range will develop continuously southwestward to fill the present offshore region west of the Hengchun Peninsula (Fig. 12(C)). In other words, the present prograding shelf with continuous supply of sediments will extend seaward and southward to build the new shelf along the mountainous coast west of Hengchun Peninsula.

This case study of the shelf morphology in relation to mountain building and foreland-basin development through time in the southwestern Taiwan margin may shed some light on the general model of the evolution of shelves in the active margins.

\section{Discussion}

Early studies suggested that the continental shelves were exposed subaerially and then submerged by relative rise of sea level or by downwarping and downfaulting at the edges of continents (Limbrgrove, 1946; Shepard 1948: Emery, 1950). Later. stratigraphic studies of marine seismic data (Vail 't al., 1977) and models of evolution of continental margins (Emery, 1980; Boillot. 1981) suggested that the formation of continental shelves is mainly influenced by sediment supply, relative changes of sea level and tectonic vertical movement. However, the present gross topography of the continental shelf worldwide is the result of erosion and sedimentation during the last one million years (late Quaternary) (Kennett. 1982).

Terraces occur commonly on the continental shelf (Kennett, 1982). They occur in active margins (e.g. shelves off Barbados: Macintyre. 1972) and stable margins (e.g. East China Sea Shelf: Jin. 1992). The Karping Shelf is terraced to the northwest and narrows and shallows to the south. Are the terraces of Kaoping Shelf erosional (e.g. from tectonic vertical movement) or

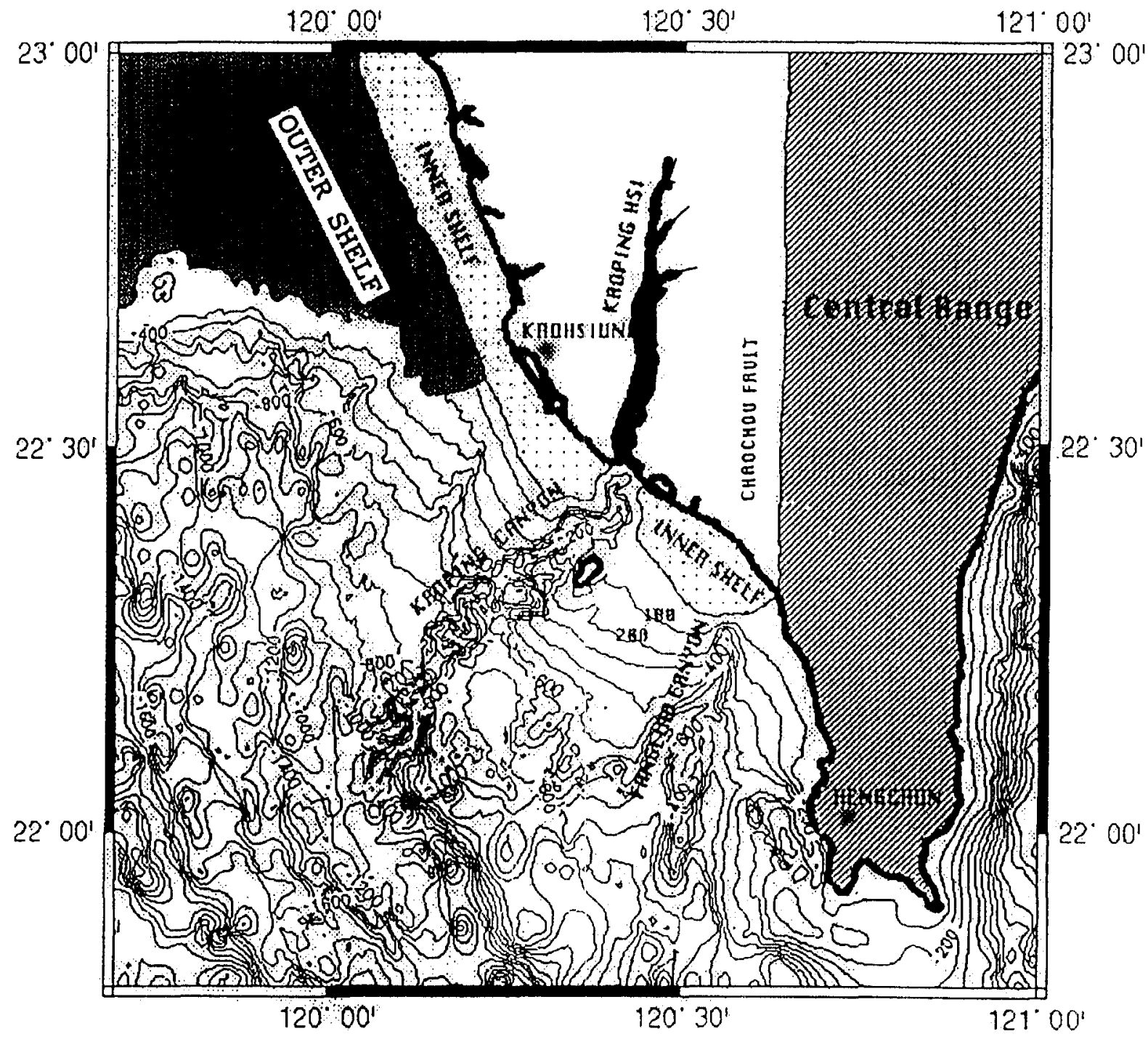

Fig. 8. The southwestern Taiwan coats is bounded be the NW Sf trending Kaoping shell off the Pingtung Valley and the N S trending umnamed submirine lope west of the Hengehun Peninsula. The boundary

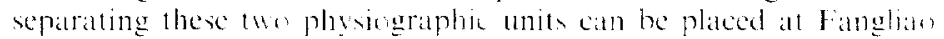




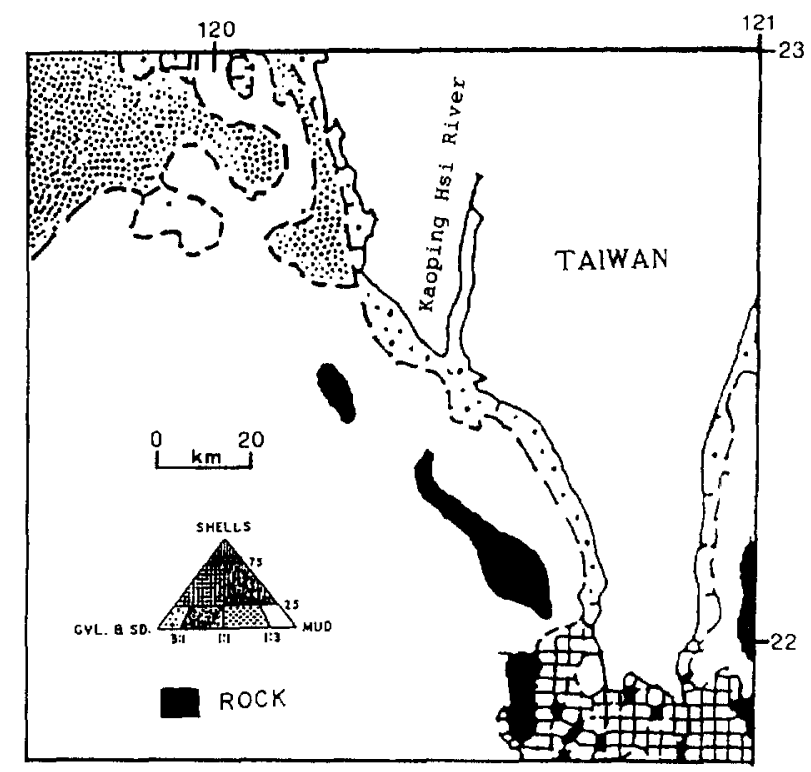

Fig. 9. A nearly continuous nearshore belt of sandy sediments present along the southwestern Taiwan coast (after Boggs et al.. 1979).

depositional (from prograding out on to pre-existing deeper shelf)? What is the effect of variations of sea level on the terraces of the Kaoping Shelf? These questions are discussed using related regional geology in the Taiwan region.

Most of the Taiwan shelf was subaerially exposed when sea level was about $140 \mathrm{~m}$ below the present leve] approximately 15,000 years ago (Boggs et al. 1979). As sea level rose in late Pleistocene time, the sea reached its present level about 6000-7000 years ago (Hopley. 1978; Boggs et al., 1979; Huang et al., 1987). On the basis of sediment properties, Boggs et al. (1979) suggested that the Holocene sediments derived from western Taiwan are unlikely to extend onto the shelf, including the Kaoping Shelf, farther than about $30-40 \mathrm{~km}$ beyond the present coastline. They also pointed out that parts of the shelf having low-reliefed and irregular topography are considered to be of probably relict subaerial erosional features.
Bathymetric profiles 1-4 (Fig. 5) show that the surface of the inner shelf is relatively smooth, which is probably the result of progradation of the Holocene sediments seaward. The inner shelf is a narrow, constructional platform with very gentle slope seaward and covered by marine sands and silts. On the other hand, the sea floors of the outer shelf show low-reliefed and irregular lopography, suggesting probable relict origin. The interpretation from the morphology revealed by bathymetric profiles $1-4$ seems to be compatible with the studies of the Taiwan Shelf by Boggs et al. (1979).

Lacking factual data, it can only be speculated that a relative stillstand of sea level occurred at the boundary between the inner and outer shelves as the sea rose and migrated toward the western Taiwan coast in late Pleistocene time. A wave-cut terrace formed along the coast now is submerged about $40 \mathrm{~m}$ below the present sea level and about $10 \mathrm{~km}$ from the Taiwan shoreline. When did the stillstand of sea level happen? How long has the stillstand of sea level lasted? The late Pleistocene geology of the East China Sea Shelf north of Taiwan may provide some answers to these two questions.

On the basis of sedimentary facies analyses and carbon-14 dating of cores recovered from the East China Sea Shelf, Jin (1992, p. 488) reported that the sea migrated westward to mainland China and reached water depth of about $60 \mathrm{~m}$ approximately 12,000 years ago. A stillstand of sea level has lasted about 1000 years at water depths of between 50 and $60 \mathrm{~m}$ and has produced a terrace along the coast. The sea then rose again and reached water depths of about $15 \mathrm{~m}$ below the prosent level approximately 8000 years ago. The present sea level is close to that about 7000 years ago. The East (hina Sea Shelf is divided into two subshelves, namely the inner shelf $(0-60 \mathrm{~m})$ and the outer shelf $(60-160 \mathrm{~m})$ (Jin, 1992, p. 7).

It seems reasonable by analogy between the late Pleistocene geology of the East China Sea Shelf and the Kaoping Shelf to assume that the terrace on the Kaoping Shelf probably formed by marine erosion about 12,000 years ago in 1000 years. The inner shelf $(0-40 \mathrm{~m})$ of the Kaloping Shelf is $20 \mathrm{~m}$ shallower than that $(0-60 \mathrm{~m})$ of the East China Sea Shelf. The difference in water depth of the terraces is probably due to the relatively high

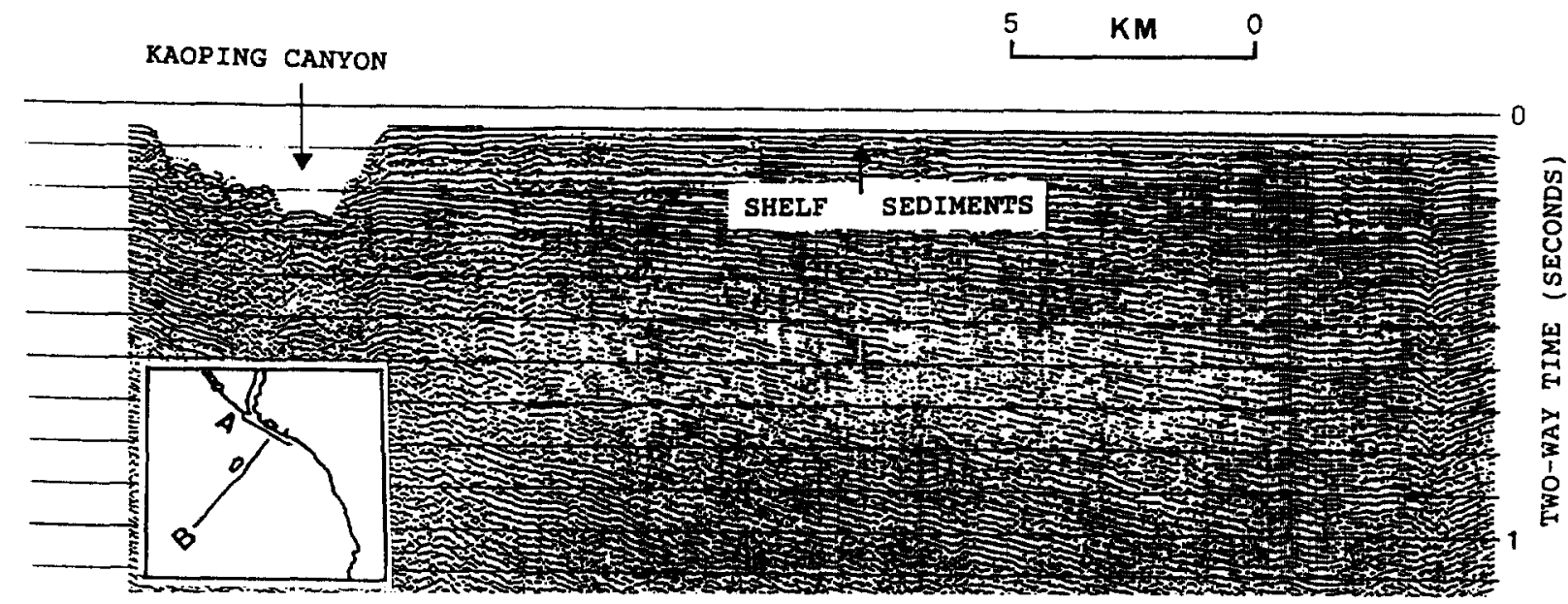

Fig. 10. Seismic protile A paralleling to the shoreline show parallel, flat-lying and continuous reflections in the upper part of the section. which are the characteristic seismic configuration of the depositional setting of the shelt 

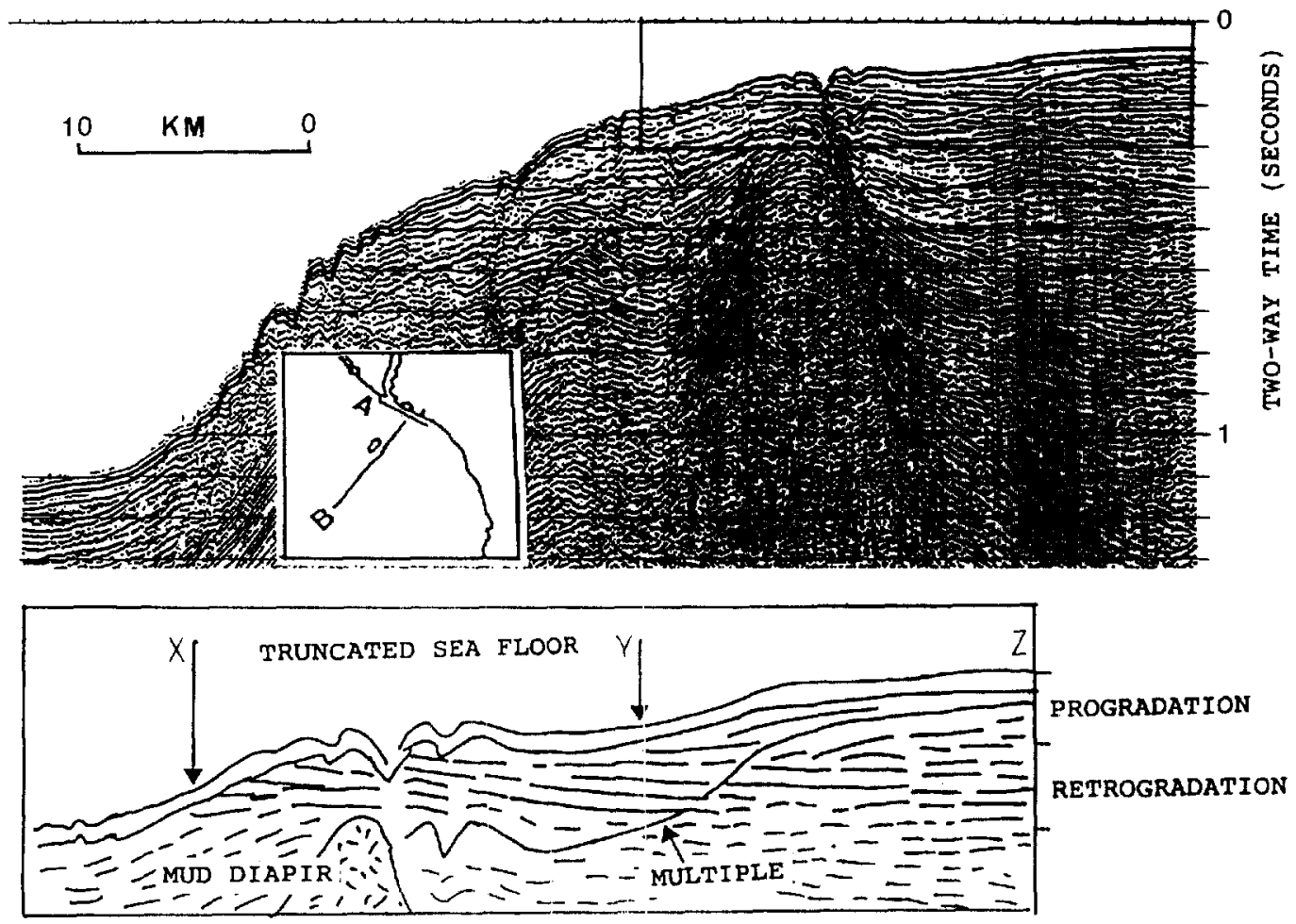

Fig. 11. Seismic profile B. a downstope section. shows terminations of reflections against the overlying sea floor (shot point $X$ - Y), suggesting erosion. The cresional truncation could be resulted from the subaerial exposure of the shelf during the lowstand of sea leval about 15.000 years ago. A progradation configuration may be recognized between shot point $Y$ and $Z$. This prograding shelf is suggested to be formed during th: recent matrine transgression.

uplift rate in southern Taiwan. The average uplift rate of the Hengchun Peninsula in southern Taiwan is $3.5 \mathrm{~mm} / \mathrm{yr}$. (Chen, 1993: Chen and Liu. 1993).

The discussion of the terrace is considered to bc inconclusive. The inferences of the terrace can be tested by additional marine studies, such as carbon-14 dating. sediment analyses of cored samples and high-resolution seismic profiling.
It is intended that the distinction between a continental shelf and an island shelf will be made here. The Katoping Island Shelf. being a young shelf built by present-day sedimentation, will be emphasized. This very narrow shelf borders the mountainous coast of the Taiwan Island, which has been iectonically uplifted since Pleistocene. This island shelf reflects continuous orogenic sediment supply and tectonic vertical move-

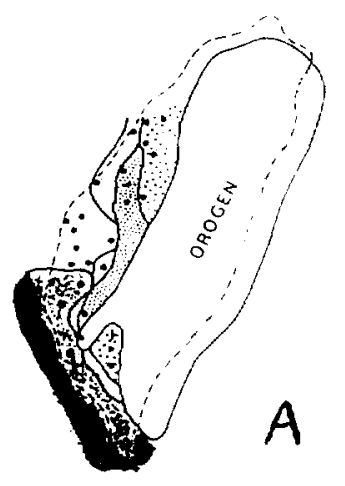

400,000 YEARS AGO

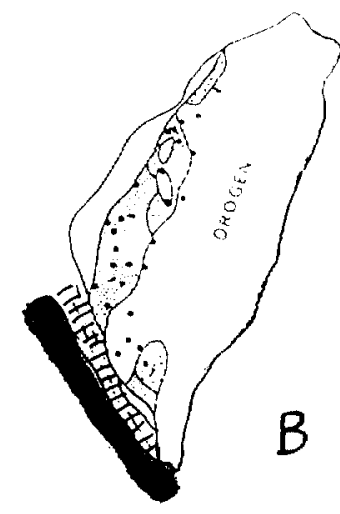

PRESENT

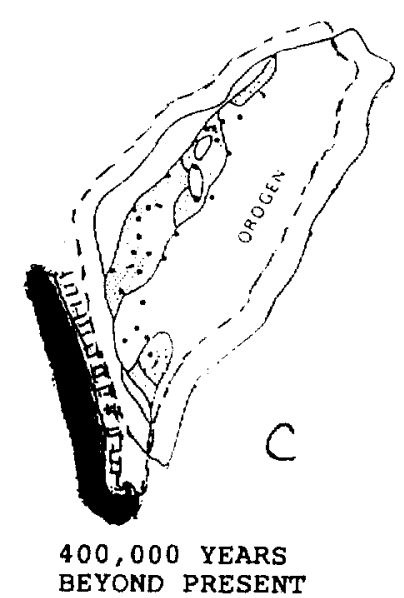

COBBLY BRAIDED RIVER

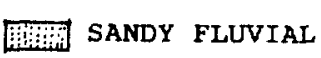

DELTAIC

PZ SHALLOW MARINE

OFFSHORE MARINE

- STUDIED WELLS OR SURFACE SECTION

Fig. 12. A hypothetical evolution for the Kaoping Shelf. southwestern Taiwan. The Pingtung Valley wats mainly filled with orogenic sediments laid down by the ancestral Kaoping Hsi River about 400,000 years ago. The Kaoping Shelf is the offshore extension of the Pingtung Valley (A). Orogenic sediments continuously supplied by the Central Range have migrated seaward to enlarge the Pingtung Valley to the present lorm (B). In another 400.000 years beyond present the shell will extend seaward and southuard to build the new shelf along the mountainous coast wex of the Hengchun Peninsula (C). Modified from Covey (1984). 
ment, which is the result of arc-continent collision. In contrast, the adjacent wide shelves of South China Sea. Taiwan Strait and East China Sea bordering Chinese coastal plains are mature shelves where tectonic vertical movement and sediment supply are minimal.

The geologic significance of the formation of this island shelf can contribute to a better understanding of models of the evolution of collisional margins, particularly in the southeast Asian region, where many small and large islands exist.

\section{Summary and conclusions}

The detailed bathymetric mapping of the Kaoping Shelf resulted in the refinement of the morphological description of the shelf and in the subdivision of the shelf into two subshelves. North of Kaohsiung. the shelf consists of an inner and an outer shelf and has an average width of $28 \mathrm{~km}$, whereas the shelf south of Kaohsiung shows a very narrow and shallow platform $(9 \mathrm{~km}$ wide and $40 \mathrm{~m}$ deep). The depth of the inner shelf edge ranges from 35 to $45 \mathrm{~m}$. with an average value of $40 \mathrm{~m}$, whereas the outer shelf edge ranges from 180 to $250 \mathrm{~m}$ in depth, with an average value of $215 \mathrm{~m}$.

The tectonic setting is the primary factor controlling the present form of the Kaoping Shelf. In terms of tectonics and sedimentation, the shelf is the offshore extension of the Coastal Plain. which contributes high amounts of sediment to build the broader platform of the shelf, whereas the slope region is underlair by the submerged Central Range. which contributes little sediment, resulting in a sediment-starved submarine slope.

Acknomledgements The authors would like to express their appreciation to the captain, crew and technicians aboard the R/V Ocean Researcher I who helped to collect marme data. J. C. Chen. Institute of Oceanography, National Tarian University. critically reviewed the manuscript. An anonymous reviewer made constructive suggestions and improned the paper greatly. This research was financially supported by the National Science Council of Republic of Chinis.

\section{REFERENCES}

Biq C. (1977) The Kenting melange and the Manila Trench. Pros Geol. Sor. China 20, 119.122

Boggs Jr S. Wang W. C.. Lewis F. S. and Chen J. ( . 11979) Sedinent propertics and water characteristics of Taiwan shelf and sope. Aite Oreanogr. Taivanica 10, 1049

Boillot G. (1981) Goology of the Cominentat Mersin. 115 pp. Longman, London.

Bouma A. H. (1990) Naming of underiea features. ceen-1/w latl. 10, 119127.

Chen Y. G. (1993) Sea-level change and neotectomics in southern part of Tatwan region since late Pleistocene. Ph. D. thests. National Taiwan University. Taipei. Taiwan. $158 \mathrm{pp}$.
Chen Y. G. and Liu T. K. (1993) Holvene radiocarbon dates in Hengchun Peninsula and their nootectonics implications. $J$. Geol. Sol. Chind 36, 457-580.

Covey M. C. (1984) Sedimentary and tectonic evolution of the western Taiwan foredeep. Ph.D. thesis. Princeton University. $151 \mathrm{pp}$. Princeton. New lersey. USA.

Emery K. O. (1950) A suggested orgen of continental stopes and submarine canyons. Geol. Mag. 87. 102104

Emery K. O. (1980) Continental margins classification and petroleum prospects. Am. Aswer Porol Gool. Bull 64, 297.315.

HoC.S (1982) Tectonic evolution of Taiwan: explanatory 10 of the lectonic map of Tawan. Mimson Fconomic Allairs. Taipes. Taiwan. Republic of China, $126 \mathrm{pp}$.

Ho C S (1986) An introduction to the gcology of Taiwan: explanatory text for the geologic map of Taiwatl. Ministry of Economic Affairs. Taipei. 'Taiwats. Republic of ( hina. $164 \mathrm{pp}$.

Hopley D. (1978) Sea level change on the Great Barrice reef: an introduction. Phil. Trams. Rolat sue. London A 291, 1.59166.

Huang K. (i. Li P. G., Zhang Z. G. and /ong Y. Q. (1987) hea-level

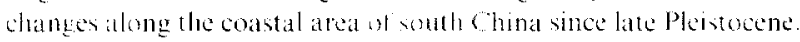

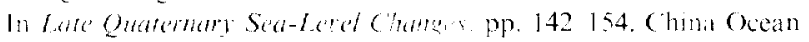
Press. Beijing Chind

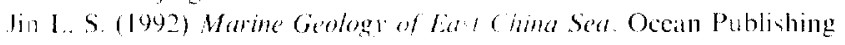
Company, Beijing, $524 \mathrm{pp}$

Kennetl J. P. (1982) Marine Geologe. I'rentice-Hall. Englenood ("liffs, VI. $813 \mathrm{Pp}$

I. Y. I1. 19976) Denudation of Taran island since the Pliocene lepoch cicolog! 4, 105107.

Macintyle I. G. (1972) Submerged rat of eastern Carbbean. Am.

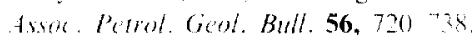

Shepard F. P. (1948) Submarinc Gables Harper and Bros, Vew York. $348 \mathrm{pp}$.

suppe I (1981) Mechanies of mountan huilding and metamorphism in Talwan. Mem. Geol. Sere. (hine th, 6789

suppe I (1987) The active Taiwan mountain bete. In Cimparatio Anatom of Mountain Ranges ledtud by Sihaer J. P. and Rogers R). 197. 277 293. Princeton University Press. Princeton. New Jersey. IISA.

ling L. S. (1990) Geotectonic evolutum at late Cenozoic atre continent collision in Taiwan. Teremophyls: $183,5776$.

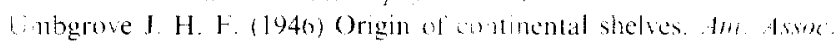
Pitrol. Gint. Bull. 30, 24925 .

Vall P. R.. Mitchum Jr R. M. and Tlumpson III S. (1977) Sesmic Watigraply and global change of hat level, part 3 . relative hanges of sea level from coastal onlap. It semmic Statigraph Appli-

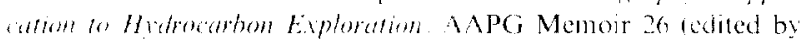

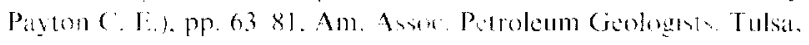
oklaboma. I SA

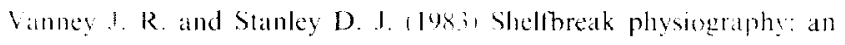

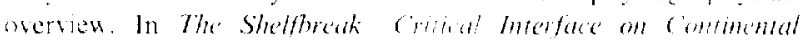
11arem. SEPM Spec. Publ. 33 lediled by Stanley D. J. and Moore G. T.1. pp. 1 24. Soc Econ. Paleontologists and Mineralogists. Tulsal. Oklahoma. USA

Ya H. S. (1993) Contrasting tectonic ste of a foredeep with a passive

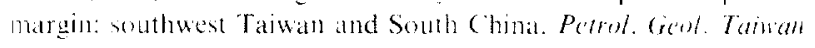
$28,97118$.

Yu H. S. and (hao L. Y. (1944, The physiography off southern Taiwan coast: morphology and its implication for trench comtinent convergence. Acta Oreangr. Tamanica 33, 21 - 37.

Yu H. S and Wen Y. H. 11992) Phesegeraphic characteristic of the contimental margin off southuestemi Tatian: f. Geal. Chima $\mathbf{3 5}$, 3,37351 . 